\title{
GSTM1 and GSTT1 Polymorphism in Egyptian Sickle Cell Anemia Patients
}

\author{
M. Aly RABAB ${ }^{1}$, M. Hasaneen BOTHINA ${ }^{2}$ \\ ${ }^{1}$ Mansoura University Faculty of Medicine, Department of Clinical Pathology \\ ${ }^{2}$ Mansoura University Faculty of Medicine, Department of Pediatry, Mansoura, EGYPT
}

\begin{abstract}
Glutathione S-transferase gene deletions are known detoxification agents and cause oxidative damage. In different studies, variations in null allele frequency have been observed. We have investigated the prevalence of the GSTM1 and GSTT1 null genotypes in sickle cell disease (SCD) patients. Thirty-seven sickle cell anemia and forty controls were evaluated to determine the frequency of Glutathione S-transferase (GST) gene deletions. Complete blood counts were performed by an automated cell analyzer. Hemoglobin $\mathrm{F}$, hemoglobin A, hemoglobin A2 and hemoglobin S were measured and diagnosis of patients was achieved by high performance liquid chromatography. The GST null genotype was determined using polymerase chain reaction (PCR) method. The prevalence of GSTM1-null genotype in SCD was 37.8\%, compared to 55.0\% in the control group (OR= 0.9, 95\% $\mathrm{Cl}=0.3-2.8, p=0.24$ ). The frequency of individuals carrying GSTT1 null genotype was higher among SCA patients (64.9\%) compared to controls (42.5\%) (Odds Ratio, $\mathrm{OR}=2.5,95 \%$ Confidence Interval, $\mathrm{Cl}=1.8-4.2, \mathrm{p}=0.015)$. Present results showed that the frequency of combined polymorphism GST1/M1 null genotypes were not statistically significant. GST11 and GSTM1 showed no statistical significance between patients and control group in relation to both clinical and laboratory findings. We have observed that GSTT1 null genotypes were high among Egyptian sickle cell anemia patients and both GSTT1 and GSTM1 null genotypes were not related to both clinical and laboratory findings in SCD patients.
\end{abstract}

Keywords: SCD, Polymorphism, GSM1, GST1

\section{ÖZET}

\section{Mısırlı Orak Hücreli Anemili Olgularda GSTTM1 ve GSTT1 Polimorfizmi}

Glutathione S-transferaz gen delesyonları detoksifikasyon ajanları olarak bilinir ve oksidatif hasara yol açarlar. Farklı çallşmalarda, null alel frekanslarında varyasyonlar gözlenmiştir. Bu çalışmada orak hücre anemili olgularda GSTM1 ve GST1 null genotip prevelansını araştırdık. 37 orak hücreli anemi ve 40 kontrol olguda Glutathione S-transferaz (GST) gen delesyonu frekansı incelendi. Tam kan sayımı sonuçları otomatik hücre analizörü ile bakıldı. Hemoglobin F, hemoglobin A, hemoglobin A2 ve hemoglobin S seviyeleri ölçüldü. Hastaların tanıları yüksek performanslı likit kromatografi tekniği ile konuldu. GST null genotipi polimeraz zincir reaksiyonu (PCR) method ile saptandı. Orak hücre anaemili olgularda GSTM1-null genotip prevelansı \%37.8, control grubunda ise \%55.0 olarak saptandı $(\mathrm{OR}=0.9,95 \% \mathrm{Cl}=0.3-2.8, \mathrm{p}=0.24)$. GST1 null genotip taşıyan birey frekansı orak hücreli anemili olgularda daha yüksekti (\%64.9 vs. 42.5\%) (Odds Ratio, $\mathrm{OR}=2.5,95 \%$ Confidence Interval, $\mathrm{Cl}=1.8-4.2, \mathrm{p}=0.015$ ). GST1/M1 null genotipinin kombine frekansında anlamlı bir fark bulunmadı. GST11 ve GSTM1 klinik ve labaratuvar bulguları açısından her iki grupta benzerdi. Sonuç olarak, GSTT1 null genotipi Mısılı orak hücre anemli olgularda daha yüksek olarak bulduk, ve gerek GSTT1 gerekse GSTM1 null genotipleri ile klinik ve labaratuvar sonuçları arasında bir ilişki saptayamadık.

Anahtar Kelimeler: Orak hücreli anemi, Polimorfizm, GSTM1, GSTT1 


\section{INTRODUCTION}

According to the World Health Organization, 270 million people possess genes that determine abnormal hemoglobins. ${ }^{12} \mathrm{Hb} \mathrm{S}$ is originated as a point mutation from the GAG (glutamic acid) codon to the GTG (Valine) codon in the sixth position of the B-globin chain. This substitution leads to alterations in the stability and solubility of the molecule and promotes polymerization in conditions with low oxygen tension.

Sickle cell disease (SCD) has become one of the best characterized monogenic human disorders. Many stud-ies have aimed to investigate genetic variations that could explain why only some patients tolerate and respond to this treatment, while the rest still need to be treated with blood transfusion-based strategies. ${ }^{4}$ The formation of this new $\mathrm{Hb}$ type $(\mathrm{HbS})$ in SCD may alter the delicate balance of free-radical generation and anti-oxidant defense systems in red blood cells, which are a significant source of free radicals in biological systems.

In the deoxygenated state, the $\mathrm{HbS}$ tends to aggregate into rod like polymers, resulting in the deformed sickle shape and rigidity of red blood cells (RBCs) characteristic of this condition. ${ }^{6}$ Normal RBCs are usually subjected to oxidative stress as a result of continuous reactive oxygen species (ROS) production that accompanies $\mathrm{Hb}$ autoxidation. $\mathrm{Au}-$ toxidation leads to SCD-derived oxidative stress consequences that include an increase in membrane lipid peroxidation levels and alterations in anti oxidant defense system. ${ }^{7.8}$

An altered glutathione (GSH) metabolism in association with increased oxidative stress has been implicated in the pathogenesis of many diseases.? Alterations in GSH concentration have been demonstrated in many pathological conditions including SCD. ${ }^{10}$ Glutathione S-transferases (GST) are a family of enzymes involved in phase-II detoxification of endogenous and xenobiotic compounds. Polymorphisms in GST genes have been associated with susceptibility to different diseases. ${ }^{11}$ The clinical severity and hematological manifestations of sickle cell anemia are varied and are influenced by the participation of several genes in modulating the phenotype of sickle cell disease; polymorphisms of these genes may be related to the different manifestations between individuals. ${ }^{12}$
Many genetic factors such as $\alpha$-thalassemia, fetal hemoglobin synthesis, and B-globin haplotype have been identified, but none of these can fully explain the differences in clinical expression observed in SCD patients. Probably, there are other elements that contribute to the many phenotypes of the disease. ${ }^{13,14} \mathrm{In} \mathrm{SCD}$, previous reviews have reported that several of these polymorphisms are associated not only with the degree of anemia, but also with pain rate, prevalence of stroke, leg ulcers, pulmonary hypertension, hepato-biliary complications and priapism, among other several clinical aspects. ${ }^{15}$ Glutathione S-transferases (GSTs) constitute multifunctional enzymes that are coded by at least eight distinct loci: $\alpha$ (GSTA); $\mu$ (GSTM); $\theta$ (GSTT); $\pi$ (GSTP); $\sigma$ (GSTS); $\kappa$ (GSTK); $\omega$ (GSTO); and $\zeta$ (GSTZ), each one composed of one or more homodimeric or heterodimeric isoforms. These enzymes are involved in the conjugation reactions between glutathione (GSH) and a variety of potentially toxic and carcinogenic compounds. Additionally, GSTs display peroxidase activity and this can protect against oxidative damage..$^{16,17}$ The deficiency in the activity of this enzyme can be derived from the inherited GSTs polymorphisms; GSTT1 (22q11.23), GSTM1 (1q13.3) and GSTP1 (11q13)..$^{18}$ Associations of GSTM1 and/or GSTT1 null genotypes with aplastic anemia and Fanconi anemia have been reported. ${ }^{19,20}$ In Egypt, there is no literature published on GST deletions in SCD. Thus the aim of this study was to estimate the prevalence of the GSTM1 and GSTT1 null genotypes and to analyze their effect on clinical severity of SCD patients.

\section{MATERIALS AND METHODS}

Participants were SCD patients attending the outpatient clinic of hematology units of Mansoura University Children Hospital. Clinical as well as demographic data were obtained from medical records and interviews with the patients or their parents. Informed consent was obtained from all patients and/or their parents. Thirty seven Egyptian subjects were included in the study (15 males and 22 females; mean age: 9.6 years old; range: 4-17 years old). Forty healthy subjects were included in the study as control group who were healthy and without medical history (15 males and 25 females; 


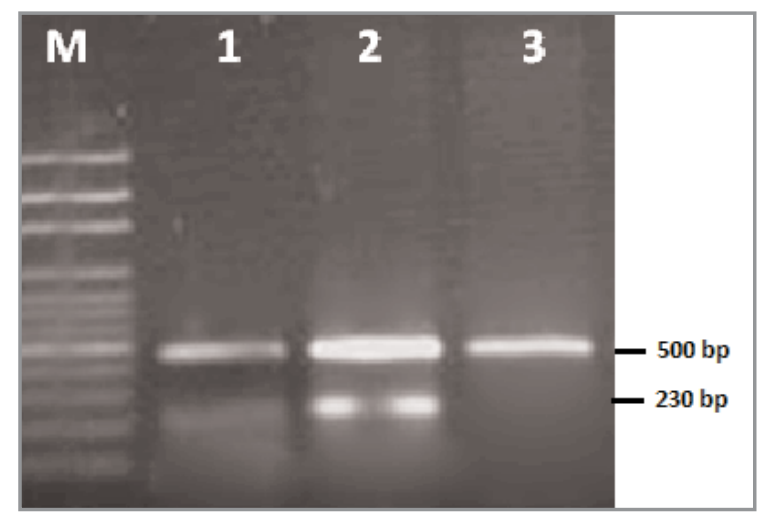

Figure 1. Agarose gel electrophoresis for amplified PCR products of GSTM1 (230 bp) and B-globulin (500 bp) fragments. Lanes1, 2 show GSTM1 positive genotype (230 bp), lanes 3 shows GSTM1 null genotype, M: marker. B-globin was used as an internal positive control (500 bp).

mean age: 8.2 years old; range: 5-16 years old). About $5 \mathrm{ml}$ blood samples were collected from patients and controls after informed consent was received from their parents. Hemoglobin ( $\mathrm{Hb} \mathrm{F}, \mathrm{Hb} \mathrm{A} 1$, $\mathrm{Hb} \mathrm{A} 2$ and $\mathrm{Hb} \mathrm{S}$ ) was measured and the diagnosis of patients was performed by high performance liquid chromatography (HPLC, Bio Rad, USA).

\section{Blood Samples and DNA Extraction}

Blood samples of $5 \mathrm{ml}$ were obtained from all cases and collected in sterile EDTA tubes. Then, whole blood was stored at $-20^{\circ} \mathrm{C}$ until use. Genomic DNA was extracted from whole blood using the established protocol for DNA extraction from blood samples using DNA extraction minikit (QIAGEN, Inc Chasworthy, CA).

\section{Analysis of GSTM1 and GSTT1 Polymorphism}

The genetic polymorphism analyses for the GSTM1 and GSTT1genes was determined by the PCR with using a housekeeping B-globin gene an internal control (Figure 1 and 2).

PCR amplifications were performed in a total volume of $25 \mu \mathrm{L}$ containing $50 \mathrm{ng}$ genomic DNA, 1X PCR buffer, $3 \mathrm{mM} \mathrm{MgCl} 2,400 \mu \mathrm{M}$ dNTPs, $1.5 \mathrm{U}$ Taq polymerase (Hoffman-LaRoche) and $4 \mu \mathrm{M}$ of each primer as follows: GSTM1 forward primer 5'GAACTCCCTGAAAAGCTAAAGC-3', reverse primer 5'-GTTGGGCTCAAATATACGGTGG-3',

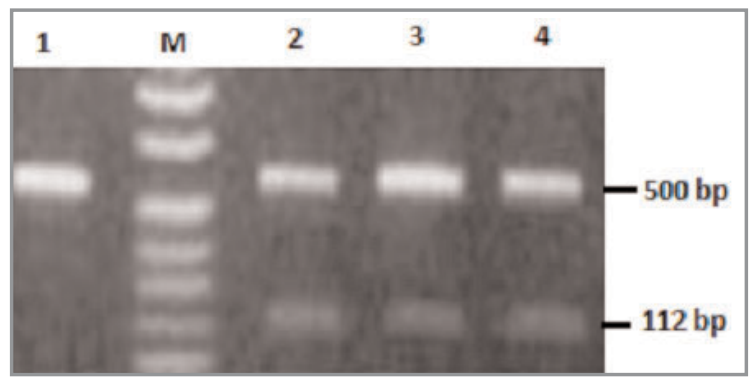

Figure 2. Agarose gel electrophoresis for amplified PCR products of GSTT1 (112 bp) and B-globulin (500 bp) fragments. Lanes2, 3 and 4 show GSTT1 positive genotype (112 bp), lane 1 shows GSTM1 null genotype, M: marker. B-globin was used as an internal positive control (500 bp).

GSTT1 forward primer 5'-TTCCTTACTGGTCCTCACATCTC-3', reverse primer 5'-TCACCGGATCATGGCCAGCA-3' and B-globin forward primer 5'-CAACTTCATCCACGTTCACC-3', reverse primer 5'-GAAGAGCCAAGGACAGGTAC-3'. Thermal cycling conditions were as follows: an initial denaturation step at $95^{\circ} \mathrm{C}$ for $5 \mathrm{~min}, 35$ cycles at $94^{\circ} \mathrm{C}$ for $1 \mathrm{~min}, 60^{\circ} \mathrm{C}$ for $1 \mathrm{~min}$ and $72^{\circ} \mathrm{C}$ for $1 \mathrm{~min}$, and a final extension step at $72^{\circ} \mathrm{C}$ for $5 \mathrm{~min}$. The amplifica-tion products were size separated on $2 \%$ agarose gels and visualized by ethidium bromide stain-ing. GSTM1 \& GSTT1 genotypes were determined by the presence and absence (null) of bands of $230 \mathrm{bp}$ and $112 \mathrm{bp}$, respectively, with an internal control of $500 \mathrm{bp}$.

\section{Statistical Analysis}

The Statistical Program SPSS for windows version 15.0 had been used in data entry and analysis. Descriptive and analytic statistics were performed. Statistical significance was determined at the 95 percent confidence interval level. The lowest accepted level of significance was 0.05 or less. Associations between the GSTM1, GSTT1 polymorphisms and SCD patients were estimated using odds ratios (ORs) and 95\% confidence intervals (95\% CIs). 


\begin{tabular}{|c|c|c|c|c|c|}
\hline Genotype & $\begin{array}{l}\text { Sickle cell anemia } \\
N=37\end{array}$ & $\begin{array}{l}\text { Control } \\
N=40\end{array}$ & $\mathrm{p}$ & OR & $95 \%$ \\
\hline \multicolumn{6}{|l|}{ GSTM1 } \\
\hline Present & $23(62.1 \%)$ & $18(45.0 \%)$ & 0.24 & 0.9 & $0.3-2.8$ \\
\hline Absent & $14(37.8 \%)$ & 22 (55.0\%) & & & \\
\hline \multicolumn{6}{|l|}{ GST11 } \\
\hline Present & $13(35.1 \%)$ & 23 (57.5\%) & 0.015 & 2.5 & $1.8-4.2$ \\
\hline \multicolumn{6}{|l|}{17 (42.5\%) } \\
\hline \multicolumn{6}{|c|}{ GSTM1/GSTT1 } \\
\hline Present & $10(27.0 \%)$ & 14 (30.0\%) & 0.19 & 1.2 & $0.9-2.7$ \\
\hline Absent & 8 (21.6\%) & 11 (27.5\%) & & & \\
\hline
\end{tabular}

\section{RESULTS}

The rate of GSTM1 null mutation was $37.8 \%$ in children with SCD, while it was $55.0 \%$ in the control group. But the difference was not statistically significant $(\mathrm{OR}=0.9,95 \% \mathrm{CI}=0.3-2.8, \mathrm{p}=0.24)$ (Table 1). The frequency of individuals carrying the GSTT1 null mutation was higher in SCD patients $(64.9 \%)$ compared to controls $(42.5 \%)(\mathrm{OR}=$ 2.5, 95\% CI=1.8-4.2, $\mathrm{p}=0.015)$. Therefore GSTT1 null genotype may be a risk factor for SCD (Table 1).Whereas no significant differences between cases and control were found in the genotype prevalence of the combined GSTM1 and GSTT1 null genotypes $(\mathrm{p}=0.19)$. Details of the frequencies of GST deletions are given in Table 1. We didn't find any significant association between both GSTT1 and GSTMT1 null genotypes and clinical severity of the disease in SCD patients (Table 2). In additi- on, both GSTT1 and GSTM1 null genotypes were not related to the laboratory findings in SCD patients (Table 3).

\section{DISCUSSION}

Sickle cell disease shows a pathophysiology that involves multiple changes in sickle cell erythrocytes, vaso-occlusive episodes, hemolysis, and activation of inflammatory mediators, endothelial cell dysfunction, and oxidative stress. These events complicate treatment and culminate in the development of manifestations such as anemia, pain crises and multior-gan dysfunction. ${ }^{21}$

The unexpected clinical diversity in a monogenic disease such as SCD has led to countless genetic studies and current knowl-edge has evolved, together with technological development in molecular

\begin{tabular}{|c|c|c|c|c|c|c|}
\hline $\mathbf{P}$ & $\begin{array}{l}\text { SCA without } \\
\text { GSTT1 } \\
\mathrm{N}=13\end{array}$ & $\begin{array}{l}\text { SCA with } \\
\text { GSTT1 } \\
\mathrm{N}=24\end{array}$ & $\begin{array}{l}P \\
N=23\end{array}$ & $\begin{array}{l}\text { SCA without } \\
\text { GSTT1 } \\
\mathrm{N}=14\end{array}$ & $\begin{array}{l}\text { SCA with } \\
\text { GSTT1 }\end{array}$ & \\
\hline 0.3 & $6(46.1 \%)$ & $11(45.8 \%)$ & 0.08 & 9 (39.1\%) & $5(35.7 \%)$ & Severe pain (\%) \\
\hline 0.1 & $4(30.7 \%)$ & 7 (29.1\%) & 0.1 & 7 (30.4\%) & $4(28.5 \%)$ & Acute chest syndrome (\%) \\
\hline 0.4 & $2(15.3 \%)$ & $4(16.6 \%)$ & 0.4 & $2(8.6 \%)$ & $1(7.1 \%)$ & Leg ulcer (\%) \\
\hline 0.5 & $0(0.0)$ & $0(0.0 \%)$ & 0.9 & $1(4.3 \%)$ & $1(7.1 \%)$ & Chronic renal failure (\%) \\
\hline 0.5 & $\mathrm{O}(0.0 \%)$ & $0(0.0 \%)$ & 0.5 & $0(0.0 \%)$ & $0(0.0 \%)$ & Priapism (\%) \\
\hline
\end{tabular}




\begin{tabular}{|c|c|c|c|c|c|c|}
\hline $\mathbf{P}$ & $\begin{array}{l}\text { SCA with no } \\
\text { GSTT1 null } \\
\text { genotype }\end{array}$ & $\begin{array}{l}\text { SCA with } \\
\text { GSTT1 null } \\
\text { genotype }\end{array}$ & $\mathbf{P}$ & $\begin{array}{l}\text { SCA with no } \\
\text { GSTT1 null } \\
\text { genotype }\end{array}$ & $\begin{array}{l}\text { SCA with } \\
\text { GSTT1 null } \\
\text { genotype }\end{array}$ & \\
\hline 0.32 & $13.4+1.8$ & $14.1+2.9$ & 0.07 & $11.2+3.3$ & $13.5+3.5$ & WBC Count $\left(\times 10^{\circ} / L\right)$ Mean \pm SD \\
\hline 0.07 & $8.7+2.5$ & $8.6+1.6$ & 0.09 & $7.5+2$ & $9.4+3$ & Neutrophil Count $\left(\times 10^{\circ} / L\right)$ Mean \pm SD \\
\hline 0.10 & $3.2+0.68$ & $2.9+0.73$ & 0.14 & $3+0.3$ & $3.2+0.25$ & Lymphocyte Count $\left(x 10^{\circ} /\right.$ L) Mean \pm SD \\
\hline 0.07 & $396+29$ & $412+27$ & 0.09 & $463+45$ & $479+25$ & Mean Platelet Count $\left(\times 10^{\circ} / \mathrm{L}\right)$ Mean \pm SD \\
\hline 0.09 & $7.95 \pm 1.35$ & $6.26 \pm 1.43$ & 0.10 & $7.77 \pm 2.25$ & $7.54 \pm 2.26$ & Haemoglobin $(g / d l)$ Mean \pm SD \\
\hline
\end{tabular}

biology. Evolution from the basic identification of polymorphic sites has provided the tools to discover the genetic complexity that affects genotype-phenotype correlation. ${ }^{12}$ Some studies involving different polymorphisms of GST have been performed in patients with SCD.22 Our study showed that GSTT1 null genotype was significantly higher amongst the SCD patients than the healthy control group. This was in agreement with previous study that was performed in India which reported a higher mean frequency of GSTT1 deletions in SCD patients. ${ }^{23}$

In our study, the prevalence of GSTM1 and GSTT1 null genotypes in the control group were 55\% and $42.5 \%$ respectively. However, some studies found lower frequency rates. They reported that GSTM1 null genotype was $44 \%$ and the GSTT1 null genotype was $14.7 \%$ in Egyptian population. ${ }^{24}$ Combined polymorphism analysis of both genes in our study revealed that $27.5 \%$ of the control group had deleted genotype of both genes. This was higher than previous study in Egyptian population. The reason for this difference between both studies was attributed to regional variation of the controls included in these studies.

Human GSTs have been well characterized as ethnic-dependent polymorphism frequencies and largely divergent among populations around the world. ${ }^{16,25}$ The frequency data obtained for the SCD patients group presented higher frequencies for the null GSTM1 (21.6\%) genotype when compared with the frequencies obtained for Brazilian population. ${ }^{26,27}$ The association of GSTM1, GSTT1 and GSTP1 polymorphisms with various diseases such as inflammatory diseases and responses in the me- tabolism, efficacy and toxicity of certain drugs have been widely investigated ${ }^{28,29}$ Knowledge of the variations in frequency of GSTM1 and GSTT1 null genotype in different population may help to explain differential responses to toxic chemicals $.^{30} \mathrm{Ho}-$ mozygous deletion of the genes at the corresponding gene loci causes the absence of the specific enzymatic activity. ${ }^{31}$ GSTM1 null genotype has been shown to be 31 to $66 \%$ in Asians and Indians. ${ }^{32-}$

${ }^{34}$ On the other hand, GSTM1 deletion polymorphism for African-Americans was found to be 23$35 \%$ and for Chileans was $21 \% .{ }^{35,36}$

Despite the small sample size, the study demonstrated that Egyptian SCD patients have high frequency of GSTT1 gene polymorphism but their effects on clinical presentation is not obvious; however, further detailed studies at the molecular level, with a larger sample size are required to show the mechanisms that influence the clinical presentation of SCD in Egyptian population.

\section{REFERENCES}

1. Clegg JB, Weatherall DJ. Thalassemia and malaria: new insights into an old problem. Proc Assoc Am Physicians 111: 278-282, 1999.

2. Bandeira FMGC, Bezerra MAC, Santos MNN, Gomes YM. Importância dos programas de triagem para o gene da hemoglobina S. Rev. Bras. Hematol. Hemoter 29: 179-184, 2007.

3. Serjeant GR. Sickle Cell Disease. 2nd ed. Oxford University Press Inc., New York, 1992.

4. Steinberg $\mathrm{MH}$. Sickle cell anemia, the first molecular disease: overview of molecular etiology, pathophysiology, and therapeutic approaches. Scientific World Journal 8: 1295-1324, 2008. 
5. Manfredini V, Lazzaretti LL, Griebeler IH, et al. Blood antioxidant parameters in sickle cell anemia patients in steady state. J Natl Med Assoc 100: 897-902, 2008.

6. Embury SH, Mohandas N, Paszty C, et al. In vivo blood flow abnormalities inthetransgenic knockout sickle cell mouse. J Clin Invest 103, 915-920, 1999.

7. Hebbel RP, Morgan WT, Eaton JW, Hedlund BE. ACcelerated autoxidation and heme loss due to instability of sickle hemoglobin, Proc Natl Acad Sci USA 85: 237-241, 1988.

8. Kato GJ, Gladwin MT. Mechanisms and clinical complications of hemolysis in sickle cell disease and thalassemia, in: MH Steinberg, BG Forget, DR Higgs DJ, Weatherall (Eds.), Disorders of Hemoglobin, Cambridge University Press,Cambridge, 2009: 201-224.

9. Reid M, Jahoor F. Glutathione in disease. Curr Opin Clin Nutr Metab Care 4: 65-71, 2001

10. Franco R, Schoneveld OJ, Pappa A, Panayiotidis MI. The central role of glutathione in the pathophysiology of human diseases. Arch Physiol Biochem 113: 234258, 2007.

11. Kavishe RA, Koenderink JB, McCall MB, et al. Severe plasmodium Falciparum malaria in Cameroon: Associated with the Glutathione S transferase M1 null genotype. Am J Trop Med Hyg 75: 827-829, 2006.

12. Fertrin KY, Costa FF. Genomic polymorphisms in sickle cell disease: implications for clinical diversity and treatment. Expert Rev Hematol 3: 443-458, 2010.

13. Rieder RF, Safaya S, Gillette P, et al. Effect of betaglobin gene cluster haplotype on the hematological and clinical features of sickle cell anemia. Am J Hematol 36: 184-189, 1991.

14. Figueiredo MS, Kerbauy J, Goncalves MS, et al. Effect of alpha-thalassemia and beta-globin gene cluster haplotypes on the hematological and clinical features of sickle-cell anemia in Brazil. Am J Hematol 53: 7276, 1996.

15. Steinberg $\mathrm{MH}$. Genetic etiologies for phenotypic diversity in sickle cell anemia. ScientificWorldJournal 18: 46-67, 2009.

16. Mo Z, Gao Y, Cao Y, et al. An updating meta-analysis of the GSTM1, GSTT1, and GSTP1 polymorphisms and prostate cancer: a HuGE review. Prostate 69: 662-88, 2009.

17. Bessa SS, Ali EM, Hamdy SM. The role of glutathione S-transferase M1 and T1 gene polymorphisms and oxidative stress-related parameters in Egyptian patients with essential hypertension. Eur J Intern Med 20: 625-30, 2009.

18. Sharma V, Kumar B, Saxena R. Glutathione S-transferase gene deletions and their effect on iron status in $\mathrm{HbE} /$ beta thalassemia patients. Ann Hematol 89: 411 414, 2010.

19. Dirksen U, Moghadam KA, Mambetova C, et al. Glutathione $S$ transferase theta 1 gene (GSTT1) null genotype is associated with an increased risk for acquired aplastic anemia in children. Pediatr Res 55: 466471, 2004.
20. Davies SM, Radloff GA, DeFor TE, et al. GST genotype may modify clinical phenotype in patients with Fanconi anaemia. Br J Haematol 131: 118-22. 2005

21. Silva DGH. Phenotypic expression of homozygous hemoglobin $S$ in relation to _-globin haplotypes, glutathione S-transferase polymorphisms and detoxification enzymes. Genet Mol Res 10: 1168-1169, 2011.

22. Zamaro P. Gene deletions of glutathione S-transferase and iron status in sickle cell patients. Rev Bras Hematol Hemoter 34: 73-79, 2012.

23. Sanjay P, Mani MR, Sweta P, et al. Prevalence of glutathione S-transferase gene deletions and their effect on sickle cell patients. Rev Bras Hematol Hemoter 34: 100-102, 2012.

24. Abdel-Rahman SZ, el-Zein RA, Anwar WA, Au WW. A multiplex PCR procedure for polymorphic analysis of GSTM1 and GSTT1 genes in population studies. Cancer Lett 107: 229-233, 1996.

25. Rossini A, Rapozo DC, Amorim LM, etal. FrequenciesofGSTM1,GSTT1 and GSTP1polymorphisms in a Brazilian population. Genet Mol Res 1: 233-240, 2002.

26. Lima MM, Oliveira MN, Granja F, et al. Lack of association of GST1, GSTM1,GSTO1, GSTP1 and CYP1A1 polymorphisms for susceptibility and outcome in Brazilian prostate cancer patients. Folia Biol 54: 102-108, 2008.

27. Pinhel MAS, Nakazone MA, Cacao JC, et al. Glutathione S-transferase variants increase susceptibility for late-onset Alzheimer's disease: association study and relationship with apolipoprotein E epsilon4 allele. Clin Chem Lab Med 46: 439-445, 2008.

28. Tamer L, Calikoglu M, Ates NA, et al. Glutathione-Stransferase gene poly-morphisms (GST1, GSTM1, GSTP1) as increased risk factors for asthma, Respirology 9: 493-498, 2004.

29. Zhong SL, Zhou SF, Chen X, et al. Relationship between genotype and enzymeactivity of glutathione Stransferases M1 and P1 in Chinese. Eur J Pharm Sci 28: 77-85, 2006.

30. Hishida A, Terakura S, Yamamato K, Murata M. GST11 and GSTM1 deletion, NQO1 C609T polymorphism and risk of chronic myelogenous leukemia in japaneese. Asian Pac J Cancer Prevent 6: 251-255, 2005.

31. Monadal BC, Paria N, Majumadr S, et al. Glutatjione Stransferase $\mathrm{M} 1$ and $\mathrm{T} 1$ null genotype frequency in chronic myeloid leukemia. Eur J Cancer Prevent, 14: 281-284, 2005

32. Ozturk O, Isbir T, Yaylim I, et al. GSTM1 and CYP1A1 gene polymorphism and daily fruit consumption in Turkish patients with non-small cell lung carcinomas. In Vivo 17: 625-632, 2003.

33. Hong YS, Chang JH, Kwon OJ, et al. Polymorphism of the CYP1A1 and glutathione-S-transferase gene in Korean lung cancer patients. Exp Mol Med 30: 192198, 1998. 
34. Persson I, Johansson I, Lou YC, et al. Genetic polymorphism of xenobiotic metabolizing enzymes among Chinese lung cancer patients. Int J Cancer 81: 325329, 1999.

35. Kelsey TK, Spitz MR, Zheng-Fa Z, Wiencke JK. Polymorphisms in the glutathione S-transferase class mu and theta genes interact and increase susceptibility to lung cancer in minuteority populations (Texas, United States). Cancer Causes Control 8: 554-559, 1997.

36. Quinones L, Berthou F, Varela N, et al. Ethnic susceptibility to lung cancer : differences in CYP2E1, CYP1A1 and GSTM1 genetic polymorphisms between French Caucasians and Chilean populations. Cancer Lett 141: 167-171, 1999.

\section{Correspondence}

Rabab ALY, MD.

Mansoura University Faculty of Medicine,

Department of Clinical Pathology

MANSOURA / EGYPT

e-mail: rababzeadah@yahoo.com 